\title{
Renal carcinogenesis in models of diabetes in rats-metabolic changes are closely related to neoplastic development
}

\author{
F. Dombrowski • L. Klotz • P. Bannasch • M. Evert
}

Received: 9 July 2007 / Accepted: 24 August 2007 / Published online: 19 October 2007

(C) Springer-Verlag 2007

\begin{abstract}
Aims/hypothesis There is an increased risk of renal cell carcinoma (RCC) in human diabetes mellitus. We therefore examined the influence of hyperglycaemia and glucoselowering treatment on nephrocarcinogenesis in rats.

Methods Rats $(n=850)$, which were either spontaneously diabetic, streptozotocin-diabetic or normoglycaemic, were examined with special reference to Armanni-Ebstein lesions (AEL).

Results Irrespective of the cause of diabetes, diabetic but not normoglycaemic rats developed typical glycogenotic clear-cell AEL. AEL showed strong proliferative activity, which was nearly completely inhibited by EGF receptor blockade (Gefitinib treatment). Many findings suggested a stepwise development of RCCs from AEL. Whereas the number and size of RCCs gradually increased in all diabetic groups, beginning at 6 months after onset of diabetes, normoglycaemic controls did not developed RCC. After 28 months, up to $82 \%$ of diabetic animals had at least one
\end{abstract}

Electronic supplementary material The online version of this article (doi:10.1007/s00125-007-0838-2) contains supplementary material, which is available to authorised users.

F. Dombrowski $(\square) \cdot$ M. Evert

Institut für Pathologie,

Ernst-Moritz-Arndt-Universität Greifswald,

Friedrich-Loeffler-Strasse 23e,

17487 Greifswald, Germany

e-mail: frank.dombrowski@uni-greifswald.de

L. Klotz

Neurologische Klinik,

Rheinische Friedrich-Wilhelms-Universität Bonn,

Bonn, Germany

P. Bannasch

Deutsches Krebsforschungszentrum Heidelberg,

Heidelberg, Germany
RCC. In contrast to the proximal tubules, the distal tubular system, including glycogenotic AEL, had the same levels of enzyme activities as RCC (e.g. high glycogen phosphorylase and synthase activity, lack of glucose 6-phosphatase activity) and the same expression patterns of cytokeratin 7 and several growth factors, along with their receptors and signal transduction proteins (TGF- $\alpha$, EGF receptor, IGF-I, IGF-I receptor, IGF-II receptor, insulin receptor substrate 1, v-raf-1 murine leukemia viral oncogene homologue 1 and mitogen activated protein kinase kinase 1). In addition, direct morphological transitions between distal tubules, AEL and RCCs were frequently observed. All these findings indicate a common origin and a precursor-product relationship of AEL and RCCs.

Conclusions/interpretation Nephrocarcinogenesis in diabetic rats results from sustained hyperglycaemia, resulting in an adaptive metabolic response, altered growth factor signalling and subsequent neoplastic transformation of the tubular epithelial cells.

Keywords Armanni-Ebstein lesion · Diabetes mellitus · Diabetic tubulopathy · Hyperglycaemia · IGF - Insulin • Nephrocarcinogenesis $\cdot$ Renal cell carcinoma $\cdot$ TGF- $\alpha$

$\begin{array}{ll}\text { Abbreviations } \\ \text { AEL } & \text { Armanni-Ebstein lesions } \\ \text { AlkPase } & \text { alkaline phosphatase } \\ \text { EGF-R } & \text { EGF receptor } \\ \text { G6Pase } & \text { glucose 6-phosphatase } \\ \text { G6PDH } & \text { glucose-6-phosphate dehydrogenase } \\ \text { GAPDH } & \text { glyceraldehyde-3-phosphate dehydrogenase } \\ \text { GST-P } & \text { gluthathione } S \text {-transferase placental form } \\ \text { H\&E } & \text { haematoxylin and eosin } \\ \text { IGF-I-R } & \text { IGF-I receptor } \\ \text { IR } & \text { insulin receptor }\end{array}$


IRS-1 insulin receptor substrate 1

MEK-1 mitogen activated protein kinase kinase 1

PAS periodic acid-Schiff

RAF-1 v-raf-1 murine leukemia viral oncogene homologue 1

RCC renal cell carcinoma

RCN renal cell neoplasm

STZ streptozotocin

\section{Introduction}

Renal cell carcinomas (RCC) have been associated with a number of risk factors, in particular cigarette smoking and exposure to certain chemical carcinogens, such as nitrosamines [1]. Long-term type 2 diabetes mellitus and related diseases, e.g. obesity, are also assumed to hold an increased risk of developing different types of cancer, including RCC [2-7]. The mechanisms leading to diabetes-related RCC are still unknown, although alterations in the diabetic kidney with a potential role in nephrocarcinogenesis, such as marked hypertrophia, have been identified [8,9]. Moreover, the overproduction of: (1) TGF- $\alpha$ and its receptor, i.e. EGF receptor (EGF-R); (2) TGF- $\beta$, IGF-I, IGF-I-receptor (IGFI-R), constituents of the mitogen-activated protein kinase and insulin receptor (IR); and (3) alterations in carbohydrate metabolism have been documented in RCC [10-13] and in diabetic kidneys $[8,9,14,15]$.

One of the most frequently used model of diabetes in rats is based on the application of a single dose of streptozotocin (STZ), causing irreversible damage to the beta cells of the islets of Langerhans and, consequently, long-term insulin deficiency. STZ has also been shown to induce RCC in rats [16]. However, it has not been clarified whether STZ acts carcinogenically by direct toxic effects on kidney tubules [17] or indirectly by induction of diabetes.

In different animal models of chemical carcinogenesis, RCCs are preceded by a group of distinct preneoplastic tubular lesions, e.g. clear-cell, basophilic, oncocytic and chromophobic tubules [18-20]. The clear-cell tubules endowed with an excessive storage of glycogen (glycogenosis) have been considered preneoplastic lesions in the rat for many years [21-24] and have also been related to human renal carcinogenesis in von Hippel-Lindau disease [25] and in sporadic cases [26]. Interestingly, this preneoplastic clear-cell tubule resembles the glycogenotic tubule of the human diabetic kidney, the so-called ArmanniEbstein lesions (AEL) [27, 28]. Despite this morphological similarity, AEL have never been investigated for its preneoplastic potential in diabetes-related nephrocarcinogenesis.

The aim of this study was to examine the influence of spontaneous and STZ-induced diabetes mellitus on renal carcinogenesis in rats, to identify potential mechanisms leading to tumour development and to investigate the possible implication of AEL in the neoplastic process.

\section{Methods}

Animals

Animals were kept under constant conditions $\left(21-22^{\circ} \mathrm{C}\right.$, $12 \mathrm{~h}$ light-dark cycle [lights on at 07:00 hours]), fed pelleted rat food, with free access to tap water. Acclimatisation time before the beginning of the experiment was at least 5 days. Housing and treatment of the animals conformed to the guidelines of the Society for Labaratory Animals Service (GV-Solas) and the German animal protection law.

\section{Experimental design}

An overview of the experimental design is given in Table 1.

Experiment 1 This experiment included 393 male Lewis rats (Harlan, Borchen, Germany) and 245 male BB/Pfd rats (breeding pairs were a kind gift of C. Mathieu, Laboratories for Experimental Medicine and Endocrinology, Rega Institute, Catholic University Leuven, Leuven, Belgium), each weighing 250 to $300 \mathrm{~g}$ at the beginning of the experiment.

Lewis rats were subdivided into four experimental groups (L1-L4). Groups L1 to L3 were made diabetic by a single subcutaneous dose of $80 \mathrm{mg} \mathrm{STZ} \mathrm{(Boehringer,}$ Mannheim, Germany) per kilogram body weight. Diabetes in L1 remained untreated and the rats stayed severely diabetic (blood glucose $>22 \mathrm{mmol} / \mathrm{l}$ ). Diabetic animals of L2 were treated by low-number isologous pancreatic islet transplantation into the liver (250 to 450 islets of Langerhans per recipient), which lowers hyperglycaemia and is intended to generate a mildly diabetic state, with blood glucose levels between 14 and $19 \mathrm{mmol} / \mathrm{l}$. The L3 animals were treated with high number pancreatic islet transplantation (1,000 islets of Langerhans), resulting in complete restoration of normoglycaemia (blood glucose $<5.5 \mathrm{mmol} / \mathrm{l}$ ). L4 rats were completely untreated and stayed normoglycaemic throughout the experiment.

The BB/Pfd rats were subdivided into three experimental groups (B1-B3). The B1 group consisted of spontaneously diabetic male $\mathrm{BB} / \mathrm{Pfd}$ rats owing to an autoimmune mechanism, similar to human type 1 diabetes mellitus, with diabetes affecting approximately $15 \%$ of our primary population $[29,30]$. Some of these received insulin implants (Linplant; Linshin Canada, Scarborough, ON, 
Table 1 Experimental design and percentages of animals showing RCNs

\begin{tabular}{|c|c|c|c|c|c|c|c|c|c|c|}
\hline & \multicolumn{10}{|c|}{ Experimental groups } \\
\hline & L1 & $\mathrm{L} 2$ & L3 & L4 & B1 & $\mathrm{B} 2$ & B3 & $\mathrm{S} 1$ & $\mathrm{~S} 2$ & $\mathrm{~S} 3$ \\
\hline Number of animals $(n)$ & 65 & 171 & 83 & 74 & 36 & 51 & 158 & 116 & 38 & 58 \\
\hline STZ treatment & Yes & Yes & Yes & No & No & Yes & No & Yes & Yes & No \\
\hline Insulin treatment & No & $\begin{array}{l}350 \\
\text { islets }\end{array}$ & $\begin{array}{l}1,000 \\
\text { islets }\end{array}$ & No & s.c. ${ }^{*}$ & No & No & No & s.c. ${ }^{*}$ & No \\
\hline $\begin{array}{l}\text { Diabetic status (blood } \\
\text { glucose level }[\mathrm{mmol} / \mathrm{l}] \text { ) }\end{array}$ & $\begin{array}{r}\text { Severe } \\
(>22)\end{array}$ & $\begin{array}{l}\text { Mild } \\
(14-19)\end{array}$ & $\begin{array}{l}\text { No } \\
(<5.5)\end{array}$ & $\begin{array}{l}\text { No } \\
(<5.5)\end{array}$ & $\begin{array}{r}\text { Severe } \\
(>22)\end{array}$ & $\begin{array}{r}\text { Severe } \\
(>22)\end{array}$ & $\begin{array}{l}\text { No } \\
(<5.5)\end{array}$ & $\begin{array}{r}\text { Severe } \\
(>22)\end{array}$ & $\begin{array}{l}\text { Mild/no } \\
(<14)\end{array}$ & $\begin{array}{l}\text { No } \\
\text { n.d. }\end{array}$ \\
\hline 4-6 months $(n)$ & 22 & 41 & 20 & 12 & 8 & 8 & 18 & 17 & 19 & 8 \\
\hline At least one neoplasm (\%) & 5 & 2 & 0 & 0 & 0 & 0 & 0 & 6 & 0 & 0 \\
\hline Multiple neoplasms (\%) & 0 & 0 & 0 & 0 & 0 & 0 & 0 & 0 & 0 & 0 \\
\hline At least one RCC (\%) & 0 & 2 & 0 & 0 & 0 & 0 & 0 & 0 & 0 & 0 \\
\hline $7-9$ months $(n)$ & 23 & 31 & 16 & 12 & 7 & 16 & 39 & 11 & 0 & 0 \\
\hline At least one neoplasm (\%) & $26^{\mathrm{a}}$ & 19 & 0 & 0 & $29^{\mathrm{c}}$ & $25^{\mathrm{c}}$ & 0 & 18 & - & - \\
\hline Multiple neoplasms (\%) & 0 & 0 & 0 & 0 & 0 & 0 & 0 & 0 & - & - \\
\hline At least one RCC (\%) & 0 & 10 & 0 & 0 & 0 & 0 & 0 & 0 & - & - \\
\hline 10-12 months $(n)$ & 11 & 15 & 9 & 10 & 11 & 15 & 44 & 13 & 9 & 8 \\
\hline At least one neoplasm (\%) & $63^{\mathrm{a}, \mathrm{b}}$ & $53^{\mathrm{a}, \mathrm{b}}$ & 11 & 0 & $36^{\mathrm{c}}$ & $53^{\mathrm{c}}$ & 0 & 31 & 0 & 0 \\
\hline Multiple neoplasms (\%) & 9 & 20 & 0 & 0 & 9 & 13 & 0 & 8 & 0 & 0 \\
\hline At least one RCC (\%) & 36 & 33 & 0 & 0 & $18^{\mathrm{c}}$ & $27^{\mathrm{c}}$ & 0 & 15 & 0 & 0 \\
\hline 13-15 months $(n)$ & 9 & 28 & 13 & 10 & 7 & 8 & 36 & 24 & 5 & 5 \\
\hline At least one neoplasm (\%) & $78^{\mathrm{b}}$ & $71^{\mathrm{b}}$ & $54^{\mathrm{b}}$ & 0 & $57^{\mathrm{c}}$ & $63^{\mathrm{c}}$ & 0 & 46 & 0 & 0 \\
\hline Multiple neoplasms (\%) & 22 & $39^{\mathrm{a}, \mathrm{b}}$ & 0 & 0 & $29^{\mathrm{c}}$ & $63^{\mathrm{c}}$ & 0 & 8 & 0 & 0 \\
\hline At least one RCC (\%) & $67^{\mathrm{a}, \mathrm{b}}$ & $61^{\mathrm{a}, \mathrm{b}}$ & 23 & 0 & $43^{\mathrm{c}}$ & $63^{\mathrm{c}}$ & 0 & 13 & 0 & 0 \\
\hline 16-18 months $(n)$ & 0 & 12 & 11 & 10 & 3 & 4 & 21 & 15 & 5 & 5 \\
\hline At least one neoplasm (\%) & - & $92^{\mathrm{b}}$ & $63^{\mathrm{b}}$ & 0 & $67^{\mathrm{c}}$ & $75^{\mathrm{c}}$ & 0 & $73^{\mathrm{d}, \mathrm{e}}$ & 0 & 0 \\
\hline Multiple neoplasms (\%) & - & $75^{\mathrm{a}, \mathrm{b}}$ & 0 & 0 & $67^{\mathrm{c}}$ & $75^{\mathrm{c}}$ & 0 & 47 & 0 & 0 \\
\hline At least one RCC (\%) & - & $75^{\mathrm{a}, \mathrm{b}}$ & 27 & 0 & $67^{\mathrm{c}}$ & $75^{\mathrm{c}}$ & 0 & 33 & 0 & 0 \\
\hline 19-21 months $(n)$ & 0 & 16 & 6 & 10 & 0 & 0 & 0 & 12 & 0 & 7 \\
\hline At least one neoplasm (\%) & - & $94^{\mathrm{a}, \mathrm{b}}$ & 33 & 0 & - & - & - & $75^{\mathrm{e}}$ & - & 0 \\
\hline Multiple neoplasms (\%) & - & $63^{\mathrm{a}, \mathrm{b}}$ & 0 & 0 & - & - & - & $58^{\mathrm{e}}$ & - & 0 \\
\hline At least one RCC (\%) & - & $81^{\mathrm{a}, \mathrm{b}}$ & 0 & 0 & - & - & - & $50^{\mathrm{e}}$ & - & 0 \\
\hline $22-28$ months $(n)$ & 0 & 28 & 8 & 10 & 0 & 0 & 0 & 24 & 0 & 25 \\
\hline At least one neoplasm (\%) & - & $82^{\mathrm{a}, \mathrm{b}}$ & 38 & 0 & - & - & - & $75^{\mathrm{e}}$ & - & 0 \\
\hline Multiple neoplasms (\%) & - & $79^{\mathrm{a}, \mathrm{b}}$ & 13 & 0 & - & - & - & $42^{\mathrm{e}}$ & - & 0 \\
\hline At least one RCC (\%) & - & $82^{\mathrm{a}, \mathrm{b}}$ & 25 & 0 & - & - & - & $46^{\mathrm{e}}$ & - & 0 \\
\hline
\end{tabular}

Tumours were only counted if they measured $>2 \mathrm{~mm}$ in diameter and proved histologically to be of renal epithelial cell origin. RCCs were defined as a renal epithelial tumour with either marked nuclear atypia, necrosis and/or haemorrhagia. All RCCs measured $>10 \mathrm{~mm}$. Data were only tested within one rat strain using Fisher's exact test; statistical significance accepted at $p<0.05$

n.d. not determined

*The s.c. insulin dose in B1 was intended to be so low that life-threatening diabetic complications were prevented but the animals still stayed in a severe diabetic state. In S2, by contrast, a therapeutic dose was used and the animals reached near or complete normoglycaemia

${ }^{\mathrm{a}} p<0.05$ compared with L3; ${ }^{\mathrm{b}} p<0.05$ compared with L4; ${ }^{\mathrm{c}} p<0.05$ compared with $\mathrm{B} 3{ }^{\mathrm{d}}{ }^{\mathrm{d}} p<0.05$ compared with S2; ${ }^{\mathrm{e}} p<0.05$ compared with S3

Canada) when they showed a weight loss of more than onethird of their maximal body weight. Insulin implants were not intended to fully compensate the diabetic state and were given only to prevent death from severe diabetic complications; thus, the blood glucose levels in these animals were lowered from approximately 33 to $22 \mathrm{mmol} / \mathrm{l}$. B2 animals did not develop spontaneous diabetes and were made diabetic by STZ administration as described for L1, resulting in blood glucose levels $>22 \mathrm{mmol} / \mathrm{l}$. They did not receive glucose-lowering treatment. B3 consisted of completely untreated normoglycaemic animals. In all animals, body weight and capillary blood glucose (tip of the tail) were measured daily.

Experiment 2 The second experiment consisted of 212 male Sprague-Dawley rats (WIGA, Charles River, Sulzfeld, Germany) weighing 225 to $310 \mathrm{~g}$. They were subdivided into three groups $(\mathrm{S} 1-\mathrm{S} 3)$. The $\mathrm{S} 1 \quad(n=116)$ and $\mathrm{S} 2(n=38)$ groups were made diabetic by a single subcutaneous dose of $65 \mathrm{mg} \mathrm{STZ} / \mathrm{kg}$ body weight. In S1, diabetes remained 
untreated, whereas S2 rats received continuous glucoselowering treatment by subcutaneous doses of insulin (Novo insulin; Novo Nordisk, Mainz, Germany). S3 rats $(n=58)$ were not treated and stayed normoglycaemic throughout the experiment.

The development of renal cell tumours was observed by killing animals from 4 to 28 months after onset of diabetes. Renal histomorphology in the first 8 weeks after diabetes induction was examined in 25 additional animals of experiment 1 and in 38 additional animals of experiment 2 . These additional animals of experiment 1 were also investigated after 2 weeks for proliferative activity of the tubular epithelium using BrdU labelling.

For the purpose of blocking the TGF- $\alpha$ receptor (EGFR), $20 \mathrm{mg} / \mathrm{kg}$ body weight Gefitinib (CD1839; kindly provided by AstraZeneca, Wedel, Germany), dissolved in $0.5 \%$ (wt/wt) carboxylmethylcellulosis (Sigma, Heidelberg, Germany), was given daily to 12 additional $\mathrm{BB} / \mathrm{Pfd}$ rats (ten diagnosed as spontaneously diabetic for 5-7 months, two normoglycaemic controls) by a pharyngeal tube for 20 consecutive days. At the 14th day of Gefitinib treatment the animals received osmotic mini-pumps for BrdU labelling.

Antigens and enzymes investigated (immuno)histochemically are listed in Table 2. Details of the staining methods, as well as a brief description of the islet transplantation procedure, means of animal death, tissue processing, BrdUlabelling and statistical analysis are given as Electronic supplementary material (ESM; Methods). For greater detail, see Dombrowski et al. [31, 32], Evert et al. [33], Scharf et al. [34], Lojda et al. [35], Hacker et al. [36], and Ahn et al. [37].

\section{Results}

Morphology of the kidneys and development of renal cell neoplasms

Armanni-Ebstein lesions In the following, proximal tubulus or proximal tubular system is defined as the tubular epithelium of the nephron, beginning at the glomerulus and ending with the descending part of Henle's loop. Distal tubulus or distal tubular system is defined as the tubular epithelium beginning with the ascending part of Henle's loop, including the cortical part of the collecting ducts.

At the beginning (up to 4 months) the kidneys of diabetic and normoglycaemic animals differed histomorphologically only in the fact that AEL were present in diabetic rats. Other diabetes manifestations (e.g. mesangiosclerosis) were seen at the earliest 1 year after diabetes induction. AEL exhibited the typical morphology of clearcell epithelial change of segments of the distal tubule system, beginning with the distal part of the Henle's loop, including the cortical parts of the collecting ducts. These
Table 2 Protein production and enzyme activity in the tubulus system and in RCNs

\begin{tabular}{llll}
\hline Protein/enzyme & $\begin{array}{l}\text { Proximal } \\
\text { tubular system }\end{array}$ & $\begin{array}{l}\text { Distal tubular } \\
\text { system and AEL }\end{array}$ & RCN \\
\hline IR & + & ++ & ++ \\
IGF-1 & 0 & ++ & ++ \\
IGF-I receptor & ++ & + & + \\
IGF-II receptor & + & ++ & ++ \\
TGF- $\alpha$ & 0 & ++ & ++ \\
EGF-R & 0 & ++ & ++ \\
GST-P & 0 & ++ & ++ \\
IRS-1 & 0 & ++ & ++ \\
RAF-1 & 0 & ++ & ++ \\
MEK-1 & 0 & ++ & ++ \\
PHO & 0 & ++ & ++ \\
SYN & 0 & ++ & ++ \\
G6Pase & ++ & 0 & 0 \\
G6PDH & + & + & ++ \\
GAPDH & + & + & ++ \\
AlkPase & ++ & 0 & 0 \\
AcPase & ++ & + & + \\
mATPase & + & ++ & ++ \\
$\gamma$-GT & ++ & + & + \\
Cytokeratin 7 & 0 & ++ & ++ \\
\hline
\end{tabular}

Semiquantitative evaluation of staining intensities in three grades: $0=$ negative or very low production/activity; $+=$ low production/activity; $++=$ moderate to strong production/activity

AcPase, acid phosphatase; $\gamma$-GT, $\gamma$-glutamyltransferase; mATPase, membrane-bound ATPase; PHO, glycogen phosphorylase; SYN, glycogen synthase

lesions were easily detectable in the periodic acid-Schiff reaction, in which they stained intensively purple (Fig. 1a). In haematoxylin and eosin-stained sections, the typical clear cytoplasm and small round nuclei with dense chromatin were recognised (Fig. 1b,c). These morphological alterations were a result of massive glycogen accumulation, confirmed by the demonstration of $\beta$-glycogen particles at the electron microscopic level (Fig. 1d). Surprisingly, at this early stage, AEL showed considerable proliferative activity, highlighted in BrdU immunohistochemistry (Fig. 1c) and described in detail below (next section). Animals that were not diabetic (L4, B3 and S3) or became normoglycaemic owing to full compensation of the diabetic state by high-number islet transplantation (L3) did not develop AEL. Mildly diabetic L2 and S2 animals exhibited less numerous AEL than the severely diabetic rats. AEL persisted throughout the experiment when the rats stayed diabetic, but some L2 animals, although they became normoglycaemic several months after diabetes induction, also showed persisting alterations in the distal tubule system that were reminiscent of AEL (Fig. 1e). Gefitinib treatment had no effect on gross and microscopic renal morphology. 


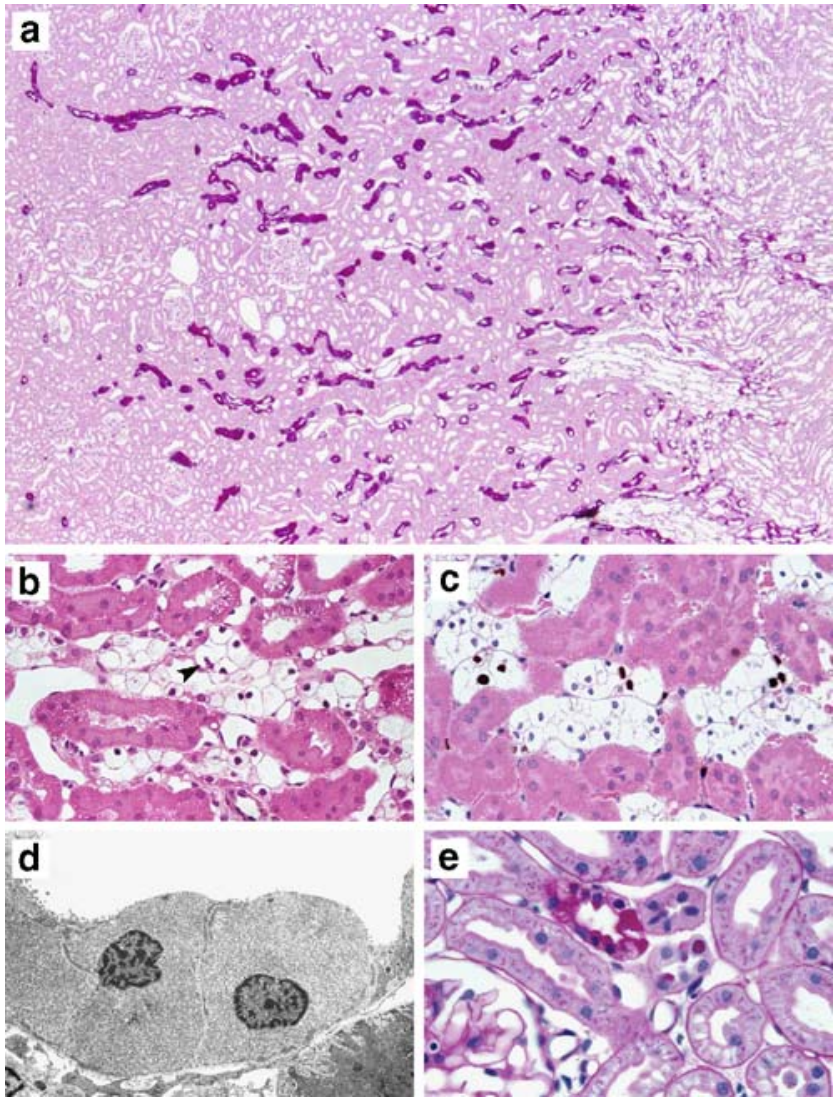

Fig. 1 Armanni-Ebstein lesions (AEL) and persisting alterations in L2 animals. a Periodic acid-Schiff (PAS) stain: distribution of PASpositive AEL within the renal cortex (left) and medulla (right). The cytoplasm of AEL cells is enlarged, staining clear in haematoxylin and eosin (H\&E) (b). The nuclei are small and pycnotic, showing condensed chromatin. The origin of AEL from the distal tubulus system is easily recognisable, considering that the adjacent cells in the same tubuli do not show that amount of glycogen storage. Proximal tubules show no glycogen storage at all. AEL are proliferative lesions, illustrated by the mitotic figure (arrowhead; b) and BrdU-labelled brown nuclei (c) (BrdU immunohistochemistry in combination with H\&E-stain). The electron micrograph (d) shows microvilli and storage of glycogen $\alpha$-particles. e PAS stain showing persistence of AELrelated cellular alterations in the kidneys of L2 animals that became normoglycaemic more than 10 months after diabetes induction owing to prolonged intrahepatic beta cell proliferation and islet graft hyperplasia. Persistence remained visible several months after animals reached normoglycaemia, as shown by single strongly glycogenstoring cells and nuclear glycogen inclusion in cells of distal tubules. Experimental group, experimental time, duration of normoglycaemia, scale relative to length of lower edge of panels: (a) L1, 6 months, $1.63 \mathrm{~mm}$; (b) B1, 11 months, $163 \mu \mathrm{m}$; (c) L1, 6 months, $275 \mu \mathrm{m}$; (d) L1, 13 months, $35 \mu \mathrm{m}$; (e) L2, 15 months, 3 months normoglycaemic, $100 \mu \mathrm{m}$

Proliferative activity of the kidney tubulus epithelium As shown in Table 3, at 2 weeks after onset of diabetes, the proliferative activity (BrdU-labelling index) of the proximal and the distal tubulus epithelium was strongly increased in STZ-induced diabetic L2 and in autoimmune-diabetic B1 animals (L2: $16.37 \pm 5.19 \%$ and $18.30 \pm 4.95 \%$; B1: $12.48 \pm$
$2.93 \%$ and $11.70 \pm 4.00 \%$, respectively) compared with the respective normoglycaemic controls L4 and B3 (L4: $4.57 \pm$ $2.80 \%$ and $4.16 \pm 2.22 \%$; B3: $2.80 \pm 0.76 \%$ and $2.70 \pm$ $0.65 \%$, respectively). At this time point, there were no differences between the proximal and distal tubules in any group.

The situation was completely different after 6 months. Whereas the proliferative activity of the proximal tubules in the diabetic animals declined to the values of the normoglycaemic controls, the distal tubular epithelium, including the AEL, continued to proliferate in all diabetic groups, albeit at a lower level than 2 weeks after diabetes induction. The proliferative activity of the distal tubular epithelium was not only two- to threefold higher compared with the distal tubules in the normoglycaemic animals (e.g. $4.71 \pm 1.67 \%$ vs $1.94 \pm 0.84 \%$ for L2 and L3 respectively and $3.36 \pm 0.76 \%$ vs $1.25 \pm 0.58 \%$ for $\mathrm{B} 1$ and $\mathrm{B} 3$ respectively), but also 1.5 - to twofold higher compared with the neighbouring proximal tubules in the same animals $(3.86 \pm$ $1.12 \%$ vs $2.31 \pm 0.85 \%$ in $\mathrm{L} 1,4.71 \pm 1.67 \%$ vs $2.34 \pm 1.20 \%$ in $\mathrm{L} 2,3.36 \pm 0.83 \%$ vs $2.23 \pm 0.52 \%$ in $\mathrm{B} 1$ ). These differences were again independent of the mode of diabetes induction. No differences between proximal and distal tubules were noted in the normoglycaemic groups L4 and $\mathrm{B} 3$.

EGF-R blockade by Gefitinib treatment drastically inhibited the proliferative activity of the distal tubular system. We noted a more than threefold reduction in normoglycaemic B3 animals $(1.25 \pm 0.58 \%$ vs $0.35 \pm$ $0.21 \% ; p=0.019)$ and a nearly 13 -fold reduction in the diabetic B1 animals $(3.36 \pm 0.76 \%$ vs $0.26 \pm 0.15 \%$; $p=$ $0.00004)$. Conversely, we found a slight 1.5 -fold increase in the number of proliferating epithelia in the proximal tubular system of diabetic but not of normoglycaemic animals.

Morphological progression of AEL Beginning after 4 months and continuing for the rest of the experiment, many AEL progressed. We noticed: (1) an increase in cell size leading to hypertrophy of the tubules; (2) cells protruding into the tubule lumen ('hobnail' cells), frequently associated with gradual loss of glycogen and increase in cytoplasmic acidophilia or basophilia; (3) nuclear enlargement and vesicular appearance with prominent nucleoli; and (4) transformation of the tubules into small solid cell clusters, which can be interpreted as microadenomas (Fig. 2). In other lesions, flattening of the epithelium occurred, which was often accompanied by cystic dilatation of the tubules. Both the solid and the cystic alterations were seen in all of the diabetic groups.

Transformation of preneoplastic tubular lesions into renal cell neoplasms Beginning at 4 to 6 months after onset of diabetes and continuing with a gradual increase, some of the tubular lesions extended in diameter and formed 
Table 3 BrdU-labelling index in proximal and distal tubular epithelium 2 weeks and 6 months after onset of diabetes

\begin{tabular}{|c|c|c|c|}
\hline \multirow{2}{*}{$\begin{array}{l}\text { Experimental } \\
\text { group and } \\
\text { time }\end{array}$} & \multirow{2}{*}{$\begin{array}{l}\text { No. of } \\
\text { animals } \\
\text { investigated } \\
\text { (n) }\end{array}$} & \multicolumn{2}{|c|}{ BrdU-positive nuclei (\%) } \\
\hline & & $\begin{array}{l}\text { Proximal } \\
\text { tubular } \\
\text { system }\end{array}$ & $\begin{array}{l}\text { Distal } \\
\text { tubular } \\
\text { system }\end{array}$ \\
\hline \multicolumn{4}{|l|}{ L1 } \\
\hline 2 weeks & 0 & n.d. & n.d. \\
\hline 6 months & 7 & $2.31 \pm 0.85$ & $3.86 \pm 1.12^{\mathrm{a}, \mathrm{b}, \mathrm{e}}$ \\
\hline \multicolumn{4}{|l|}{ L2 } \\
\hline 2 weeks & 7 & $16.37 \pm 5.19^{b}$ & $18.30 \pm 4.95^{\mathrm{b}}$ \\
\hline 6 months & 7 & $2.34 \pm 1.20$ & $4.71 \pm 1.67^{\mathrm{a}, \mathrm{b}, \mathrm{e}}$ \\
\hline \multicolumn{4}{|l|}{ L3 } \\
\hline 2 weeks & 0 & n.d. & n.d. \\
\hline 6 months & 7 & $3.23 \pm 1.13^{\mathrm{b}}$ & $1.94 \pm 0.84^{\mathrm{e}}$ \\
\hline \multicolumn{4}{|l|}{ L4 } \\
\hline 2 weeks & 7 & $4.57 \pm 2.80$ & $4.16 \pm 2.22$ \\
\hline 6 months & 7 & $1.81 \pm 0.75$ & $1.50 \pm 0.53$ \\
\hline \multicolumn{4}{|l|}{$\mathrm{B} 1$} \\
\hline 2 weeks & 5 & $12.48 \pm 2.93^{\mathrm{c}}$ & $11.70 \pm 4.00^{\mathrm{c}}$ \\
\hline \multicolumn{4}{|l|}{6 months } \\
\hline Untreated & 9 & $2.23 \pm 0.60^{\mathrm{d}}$ & $3.36 \% \pm 0.76^{\mathrm{c}, \mathrm{d}, \mathrm{e}}$ \\
\hline Gefitinib & 10 & $3.47 \pm 1.65^{\mathrm{c}}$ & $0.26 \pm 0.15^{\mathrm{e}}$ \\
\hline \multicolumn{4}{|l|}{ B3 } \\
\hline 2 weeks & 6 & $2.80 \pm 0.76$ & $2.70 \pm 0.65$ \\
\hline \multicolumn{4}{|l|}{6 months } \\
\hline Untreated & 8 & $1.70 \pm 0.59$ & $1.25 \pm 0.58^{\mathrm{d}}$ \\
\hline Gefitinib & 2 & $2.00 \pm 0.28$ & $0.35 \pm 0.21^{\mathrm{e}}$ \\
\hline
\end{tabular}

Values are \pm SD. BrdU was given by osmotic minipumps for six consecutive days before animals were killed. In the diabetic groups, the data of the distal tubulus included the AEL. B1 and B3 late-stage animals were subdivided regarding Gefitinib treatment Differences between 2 weeks and 6 months were not tested. Wilcoxon-MannWhitney test, $p<0.05$ n.d. not determined

${ }^{\mathrm{a}} p<0.05$ for difference from L $3 ;{ }^{\mathrm{b}} p<0.05$ for difference from L4; ${ }^{\mathrm{c}} p<0.05$ for difference from $\mathrm{B} 3 ;{ }^{\mathrm{d}} p<0.05$ for difference from Gefitinib-treated animals; ${ }^{\mathrm{e}} p<0.05$ for difference from proximal tubulus

adenomas (Table 1). These adenomas were either cystic or solid. Tumour cells were usually arranged in a trabecular/ tubular pattern and exhibited a clear, acidophilic or basophilic cytoplasm as observed in the tubular precursor lesions. Between 4 and 9 months, the vast majority of tumours were small (tumour diameter $2-5 \mathrm{~mm}$ ) and showed no severe cytologic atypia, necrosis or any other sign of malignancy. The mean tumour diameter increased two- to threefold between 7 and 9 months (range of all diabetic groups: $0.45 \pm 0.26-1.15 \pm 1.53 \mathrm{~cm}$ ) and 16 and 18 months (range: $1.29 \pm 0.74-2.27 \pm 1.06 \mathrm{~cm}$ ). After 22 to 28 months, the mean diameter of all tumours in L2 animals was $3.28 \pm$ $0.99 \mathrm{~cm}$. This gradual increase in tumour size was accompanied by an increase in the frequency of cellular atypia, necrosis, haemorrhage and gross or vascular invasion, justifying the classification of many tumours as
RCCs at this stage of the experiment (Fig. 3). The mixed, but predominating, basophilic cell pattern of the adenomas was preserved in the RCC.

Distribution of renal cell neoplasms in the experimental groups Table 1 gives the frequencies of animals that exhibited at least one or multiple renal cell neoplasms $(\mathrm{RCN})$, i.e. adenomas and carcinomas combined. In addition, RCCs were listed separately.

The completely untreated control rats of L4, B3 and S3 never developed clear or basophilic cell tumours larger than $2 \mathrm{~mm}$. S2 animals, which stayed normoglycaemic for most of the experimental time owing to s.c. insulin injections, also developed no RCN. In L3, a delayed and, in comparison with the hyperglycaemic groups, considerably

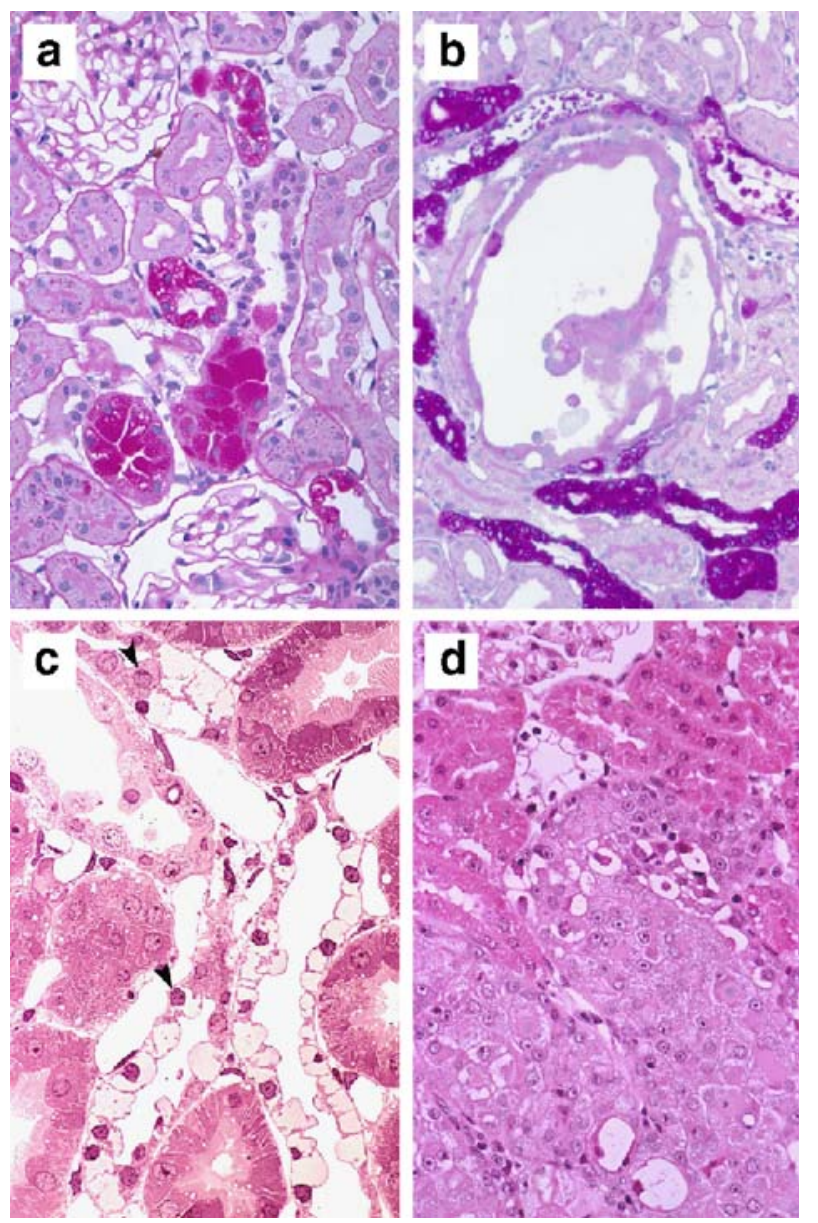

Fig. 2 Advanced tubular lesions. Stepwise progression from AEL to RCN. a Periodic acid-Schiff (PAS) stain showing glycogen-storing tubules which are larger than usual AEL. Cystic transition is accompanied by loss of glycogen (b) (PAS stain). c Nuclear changes in the distal nephron and AEL (semithin section, haematoxylin and eosin $[\mathrm{H} \& \mathrm{E}]$ stain) including nuclear grooves (arrowheads) in cells storing less glycogen. d Transition from tubular to nodular growth in an acidophilic lesion (H\&E stain). Experimental group, experimental time, scale relative to length of lower edge of panels: (a) L2, 12 months, $132 \mu \mathrm{m}$; (b) L2, 15 months, $165 \mu \mathrm{m}$; (c) L2, 13 months, $66 \mu \mathrm{m}$; (d) B1, 14 months, $132 \mu \mathrm{m}$ 


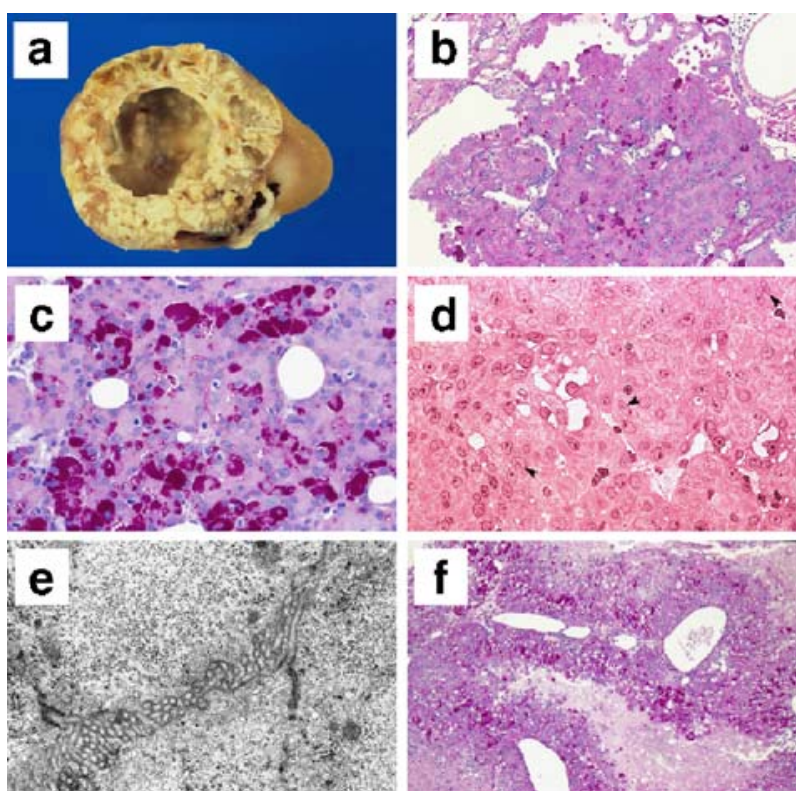

Fig. 3 Renal cell tumours. Macroscopic aspect of an RCC with necrosis and secondary cystic change (a), auto-immune diabetic B1 animal. b Periodic acid-Schiff (PAS) stain of papillary cystic tumour showing single glycogen storing cells. Most nodular small tumours showed an increase in cytoplasmic basophilia, but (c) (PAS stain) might exhibit glycogen storage in the cytoplasm or nuclei in a proportion of cells. Nuclear morphology (d) (semi-thin section, haematoxylin and eosin stain) with grooves (arrowheads) in an acidophilic tumour. Glycogen-storing cells in solid tumours often showed brush-border-like densely packed microvilli (e) (electron micrograph). f Histology of the tumour depicted in (a), showing necrosis of a clear/acidophilic cell carcinoma (PAS stain). Experimental group, experimental time, scale relative to length of lower edge of panels: (a) B1, 17 months, macroscopic overview; (b) L2, 13 months, $420 \mu \mathrm{m}$; (c) L1, 13 months, $342 \mu \mathrm{m}$; (d) L2, 18 months, $210 \mu \mathrm{m}$; (e) L2, 13 months, $38 \mu \mathrm{m}$; (f) B1, 17 months, $1.37 \mathrm{~mm}$

weaker tumour development was noted. In this group, the majority of animals that actually developed tumours showed single small adenomas measuring between 0.5 and $1.3 \mathrm{~cm}$. Only after 22 to 28 months, did we notice animals carrying multiple neoplasms in the L3 group, two of them also with an RCC. The slightly increased incidence of RCNs after lag periods of more than 13 months (Table 1) was statistically significant when compared with the completely untreated L4 rats, indicating a relatively weak and slowly progressing neoplastic process in the kidneys of the L3 group.

By contrast, a strong nephrocarcinogenic effect was demonstrated in all of the long-standing diabetic animals, regardless of whether diabetes was induced by STZ (as in L1, L2, B2 and S1) or by an autoimmune disorder (B1). It was also irrelevant whether hyperglycaemia was mild (in L2) or severe (L1, B1, B2, S1). Moreover, the conversion from hyperglycaemia to normoglycaemia in a proportion of L2 animals at late stages of the experiments did not lead to a decline in tumourigenesis. In fact, the highest incidence of tumours was noted in late-stage L2 animals: The proportion of animals exhibiting at least one neoplasm peaked at 19 to 21 months (94\%) and the proportion of rats showing multiple RCNs $(79 \%)$ or RCCs $(82 \%)$ at 22 to 28 months. Despite some minor quantitative differences, tumourigenesis was almost similar in all of the long-standing hyperglycaemic groups and was always significantly higher than in normoglycaemic controls (Table 1).

Enzyme histochemical data

As seen in Fig. 4 and Table 2, in the distal tubules, including the AEL, the enzymes glucose 6-phosphate dehydrogenase (G6PDH), glyceraldehyde-3-phosphate dehydrogenase (GAPDH), acid phosphatase, membranebound ATPase and $\gamma$-glutamyltransferase had only low activities, whereas glycogen phosphorylase and glycogen synthase showed moderate to strong activities. Glucose-6phosphatase (G6Pase) or alkaline phosphatase (AlkPase) activities were not demonstrable in the distal tubules. It was of particular interest that the enzyme histochemical pattern of the advanced preneoplastic lesions and the RCN, including the RCC, was nearly the same as that of the distal tubular epithelia and the AEL, but was in strong contrast to that of the proximal tubulus. Only the activities of G6PDH and GAPDH were elevated in the neoplasms when compared with the distal tubules.

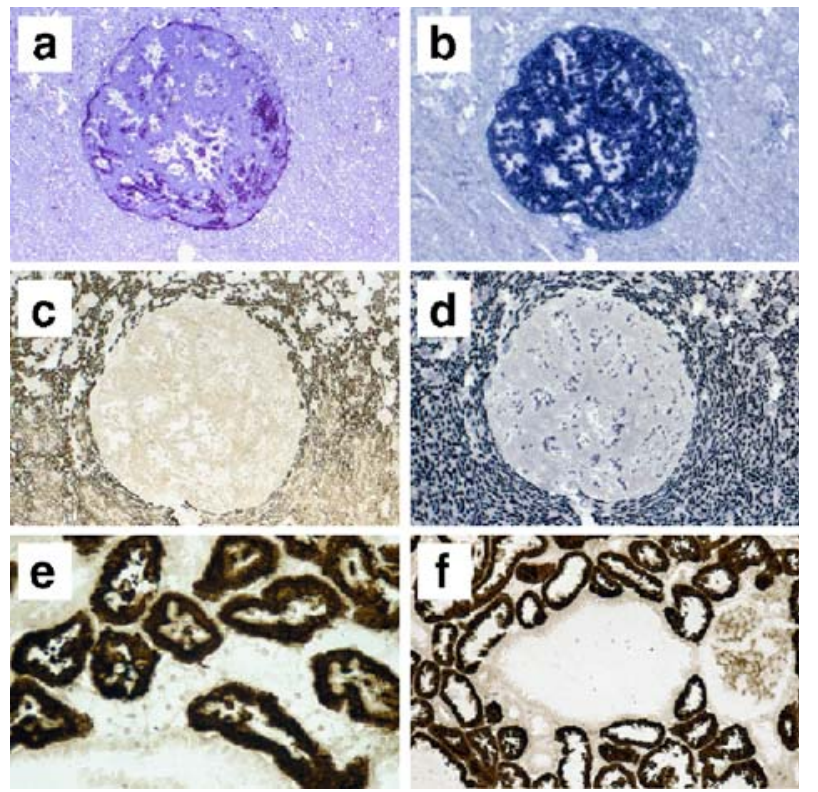

Fig. 4 Enzyme activities. a-d Serial sections of a small basophilic tumour of S1. Glycogen storage is demonstrated in the periodic acidSchiff stain (a); also shown: the increase in G6PDH (b), sparse or no activities of G6Pase (c) and AlkPase (d). e Low or absent activity of G6Pase in AEL and in a small cystic tumour (f) Experimental group, experimental time, scale relative to length of lower edge of panels: (a-d) S1, 17 months, $2.6 \mathrm{~mm}$; (e) B1, 9 months, $163 \mu \mathrm{m}$; (f) L2, 15 months, $325 \mu \mathrm{m}$ 


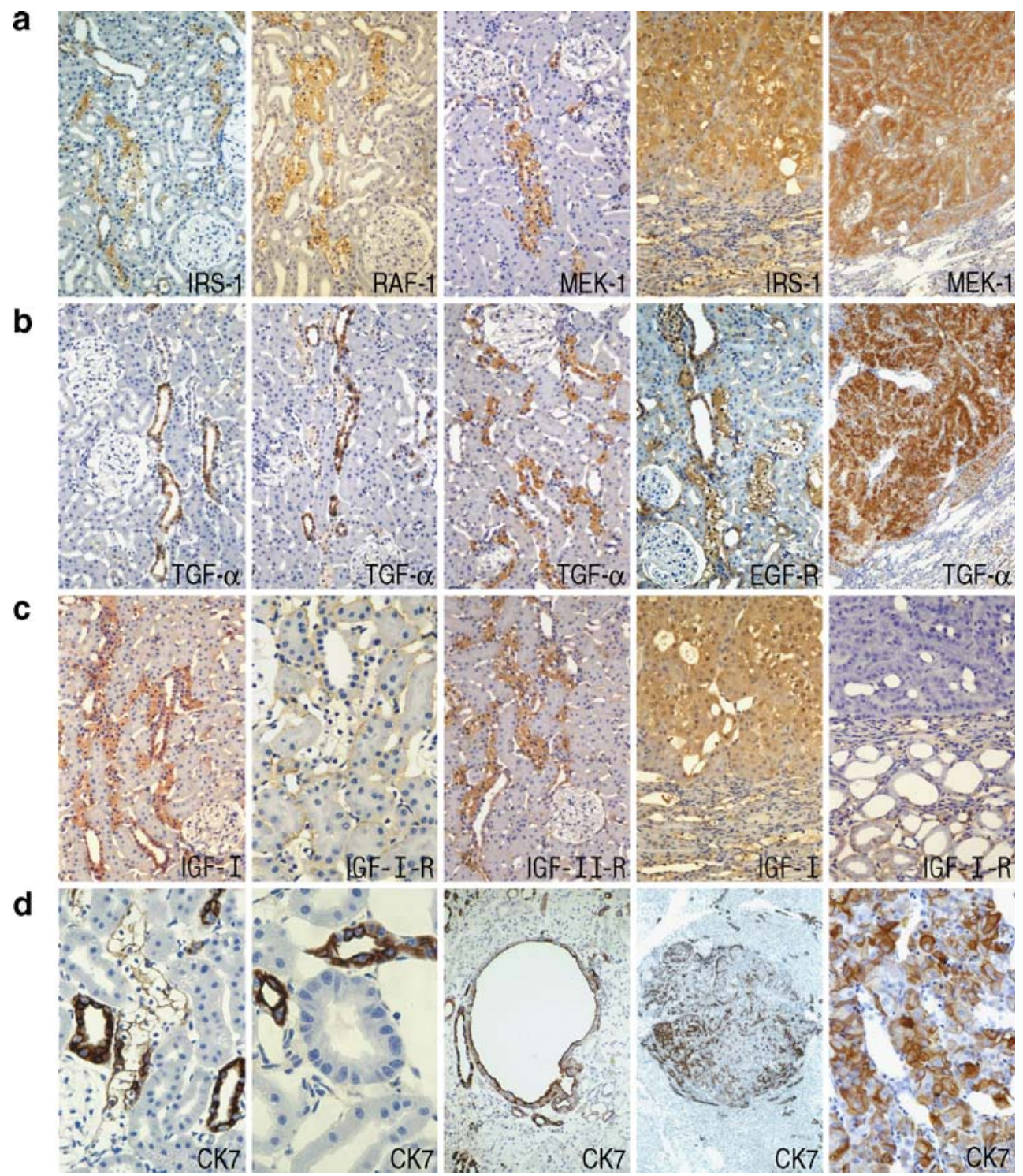

Fig. 5 Growth factors, signal transduction and cytokeratin 7. Immunohistochemistry of (a) insulin signalling transduction, (b) TGF- $\alpha$ and its receptor EGF-R, (c) IGF axis and (d) cytokeratin 7 (CK7). a Insulin signal transduction proteins IRS-1, RAF-1 and MEK1 were strongly produced in AEL (columns 1-3), while MEK-1 and IRS-1 were also strongly produced in RCN (columns 4 and 5). b TGF$\alpha$ was produced in collecting ducts in normoglycaemic animals (column 1), was weakly positive in AEL a few weeks after diabetes induction (column 2) and increased to strong production in AEL at 9 months after diabetes induction (column 3). EGF-R was strongly produced in AEL (column 4). All tumours were positive for TGF- $\alpha$ (column 5). c IGF-I was produced in AEL and RCN (column 4). The IGF-I-R was negative in distal tubules in AEL (column 2) and RCN (column 5), while proximal tubules showed a distinct staining pattern of the basal cell membrane (columns 2 and 5). IGF-II receptor was strongly produced in AEL (column 3). d CK7 levels in diabetic animals during renal carcinogenesis additionally demonstrated the tumour origin from distal tubulus system. AEL in diabetic animals (column 1) showed CK7 production at the periphery of the glycogenotic cytoplasm. The distal tubulus system, including collecting ducts, was strongly positive in contrast to the proximal tubules. In addition, potentially preneoplastic basophilic proximal tubules (note the complete brush border) were also negative for CK7 (column 2). All tumours that originated in this model retained CK7 production, including small cystic adenomas (column 3), medium-sized tubulopapillary renal neoplasms (column 4) and the later developing RCCs (column 5). Experimental group, experimental time: (a): column 1, L2, 6 months; column 2, L1, 6 months; column 3, B1, 9 months; column 4, L2, 15 months; column 5, B1, 13 months; (b): column 1, L4, 6 months; column 2, L2, 1 months; column 3, B1, 9 months; column 4, L1, 9 months; column 5, B1, 13 months; (c): column 1, B1, 9 months; column 2, B1, 9 months; column 3, L1, 3 months; column 4, L2, 15 months; column 5, L2, 13 months; (d): column 1, L1, 9 months; column 2, L2, 18 months; column 3, L2, 14 months; column 4, B1, 15 months; column 5, L2, 19 months. Lower edge of panel is always $212 \mu \mathrm{m}$, except: (c) column 2, $106 \mu \mathrm{m}$; (c) column 5, $130 \mu \mathrm{m}$; (d) column 1, $108 \mu \mathrm{m}$; (d) column 2, $67 \mu \mathrm{m}$; (d) column 3, $270 \mu \mathrm{m}$; (d) column 4, $670 \mu \mathrm{m}$; (d) column 5, $130 \mu \mathrm{m}$ 
The enzyme histochemical data point towards a close relationship between the AEL/distal tubules on the one hand and the RCN on the other.

\section{Immunohistochemical data}

As seen in Fig. 5 and Table 2, epithelia of the distal tubules, including the AEL, showed moderate levels of IR and the downstream signalling cascade, including insulin receptor substrate 1 (IRS-1), v-raf-1 murine leukemia viral oncogene homologue 1 (RAF-1) and mitogen activated protein kinase kinase 1 (MEK-1), whereas the proximal tubules showed only weak or no signals. TGF- $\alpha$ and its receptor EGF-R were also strongly produced in the distal tubules, but not in the proximal tubules. In the latter, moderate levels of the IGF-I-R, but not of IGF-I, was noticed, while the distal tubular epithelium moderately produced IGF-I, while the production of its receptor was only weak. IGF-II receptor production was pronounced in the distal tubules. Gluthathione $S$-transferase placental form (GST-P) and cytokeratin 7 were strongly produced in the distal tubules, but not in the proximal ones. Gefitinib-treatment had no effect on immunohistochemical TGF- $\alpha$ and EGF-R production.

The immunohistochemical results in the advanced preneoplastic lesions and RCN, including RCCs, showed a production profile nearly congruent with that of the AEL and the distal tubular system and in sharp contrast to the proximal tubulus. Thus RCN and the distal tubular system exhibited exactly the same production pattern of factors related to insulin signalling (IR, IRS-1, RAF-1, MEK-1) and also of TGF- $\alpha$, EGF-R, IGF-I, IGF-I-R, IGF-II-R, GST-P and cytokeratin 7.

In addition to the enzyme histochemical data, the levels of several growth factors and their receptors, as well as of GST-P and cytokeratin 7, also strongly suggests a close relationship between the RCN and the distal tubular system, including the AEL.

Additional data on findings (intercurrent diseases and basophilic/oncocytic lesions) are given as electronic supplementary material, results.

\section{Discussion}

In this study, we demonstrated a strong association between experimentally induced diabetes mellitus in rats and the development of RCC. The strongest argument is the development in the autoimmune-diabetic BB/Pfd rats (group B1), which had a high rate of RCC without administration of any exogenous carcinogenic agent. This study also shows that the main nephrocarcinogenic effect of STZ is also dependent on induction of diabetes mellitus because RCC development in STZ-treated hyperglycaemic animals clearly outnumbered that in STZ-treated rats that were subsequently made normoglycaemic by glucose-lowering treatment (L1 and S1 vs L3 and S2, respectively). Nevertheless, the slightly elevated tumourigenesis in STZ-exposed but normoglycaemic L3 rats demonstrates a minor additional carcinogenic influence of STZ on the tubular epithelium that is independent of diabetes mellitus. The lack of this effect in STZexposed S2 animals may be related to the lower dose of STZ administered in this group and/or to a lower susceptibility of the Sprague-Dawley strain. These experimental results corroborate the conclusions drawn from large epidemiological human studies documenting a higher incidence of RCCs in patients with diabetes mellitus when compared with the normal population $[2-4,6]$.

Furthermore, our study provided evidence for an interesting putative preneoplastic precursor lesion in diabetes-induced nephrocarcinogenesis, namely the diabetic tubulopathy of the kidney, known as AEL. AEL exhibit the same light microscopic appearance as clear-cell (glycogenotic) tubules of the kidney, which have previously been shown to represent preneoplastic lesions potentially progressing to clear and clear/acidophilic cell carcinomas in other models of renal cell carcinogenesis [18-24, 37]. The majority, at least, of these clear-cell tubules derive from the distal nephron, as do AEL [20, 37, 38]. However, storage of glycogen in proximal tubules and/or a connection of typical clear-cell tubules with the proximal nephron has rarely been found by histochemical and stereological approaches, respectively [20, 23, 38]. In addition to the preneoplastic tubules induced by various chemicals, AEL also share distinct morphological, immunohistochemical and enzyme histochemical features with preneoplastic glycogenotic foci of the liver, known from hepatocarcinogenesis induced in different animal models by chemicals, hormones and viruses, e.g. excessive glycogen storage, condensed nuclear chromatin, increase in proliferative activity, production of TGF- $\alpha$ and GST-P, increased levels of IRS-1, RAF-1 and MEK-1, and decreased G6Pase activity [31-33, 39-44].

For a long time, AEL have been regarded as a consequence of the re-absorption of glucose entering the tubular lumen in patients with persisting hyperglycaemia during long-term diabetes, a phenomenon considered to be reversible after normalisation of blood glucose levels. However, although the accumulation of glycogen in the distal tubules disappeared after treatment of diabetes by pancreatic islet transplantation, some ultrastructural alterations of these cells, e.g. lack of the basolateral infoldings, persisted after normalisation of blood glucose levels [45].

Our findings of persisting morphological alterations, reminiscent of AEL in normoglycaemic L2 animals, and, even more importantly, the increased proliferative activity and production of proteins related to cell growth and proliferation in AEL clearly demonstrate that AEL are at least not a completely reversible and certainly not a degenerative phenonemon. 
The congruent production pattern of growth factors, their receptors, signal transduction pathways (TGF- $\alpha$, EGF-R, IR, IGF-I, IGF-I-R, IGF-II-R, IRS-1, RAF-1, MEK-1 and GST-P) and similar enzyme activities (glycogen phosphorylase, glycogen synthase, G6Pase, AlkPase, $\gamma$-glutamyltransferase and membrane-bound ATPase) in the distal tubules/AEL on the one hand and in RCC on the other hand further support the notion of a putative preneoplastic character of the AEL in the diabetic rat kidney. These observations not only favour a precursor-product relationship between AEL and RCC, but also suggest an involvement of the related cellular alterations in the mechanism of neoplastic transformation, because chemically and diabetesinduced RCC share several metabolic features, including activities of enzymes of carbohydrate metabolism, such as GAPDH, G6PDH, G6Pase and AlkPase [37, 46]. The importance of the IGF-system in diabetes-related kidney diseases has been extensively investigated $[8,9,14,15]$ and its involvement in RCC has also been described [11]. Moreover, a large number of RCC and their preceding preneoplastic lesions strongly produce TGF- $\alpha$ and EGF-R $[47,48]$. In this study, TGF- $\alpha$ and EGF-R were strongly produced both in the carcinomas and in the distal tubules, including AEL, but not in the proximal tubules. The autocrine loop of TGF- $\alpha$ EGF-R signalling on AEL cell proliferation, already inferred from the immunohistochemical results, was verified by Gefitinib treatment, which nearly completely prevented AEL/distal tubular cell proliferation. Thus, TGF- $\alpha / E G F-R$ signalling appears to be involved in mediating cell proliferation in late-stage preneoplastic AEL and probably also in subsequent tumour development. However, additional long-term studies are needed to clarify the exact role of the different growth factor systems for RCC development in diabetic rats.

In conclusion, we have shown that long-lasting diabetes mellitus induces RCC in spontaneously and STZ-diabetic rats. Severe alterations in the metabolism of cells in the distal tubular system, including activation of different growth factor signalling pathways, are on the one hand responsible for the formation of distinctive glycogenotic tubular lesions, known as AEL, and are also clearly involved in the subsequent stepwise neoplastic transformation of AEL into RCC. Thus, AEL are identified as the principal preneoplastic lesion in diabetes-related rat nephrocarcinogenesis. It would now be of great interest to investigate whether similar metabolic alterations might also be responsible for the well-known development of RCC in human patients suffering from diabetes mellitus.

Acknowledgements The authors wish to thank G. Becker, J. Bedorf, D. Chrobok, M. Dombrowski, K. Herrmanns, R. Landeck, R. Schwarz, N. Wolf and S. Wolf-Kümmeth for excellent technical assistance, $\mathrm{H}$. Zerban for conducting animal experiment 2, K. Beck for enzyme histochemistry, K. Rüdel, L. Slobodzian and Y. Fischer for animal care, as well as B. Wüsthoff for editing the manuscript. Part of the results were presented on occasion of the 90th annual meeting of the German Society for Pathology (Deutsche Gesellschaft für Pathologie) in Berlin, 2006 [49].This study was supported by Deutsche Forschungsgemeinschaft (German Research foundation), grant numbers: Do 622/1-4, 1-5 and 2-1.

Duality of interest The authors declare that there is no duality of interest associated with this manuscript.

\section{References}

1. Outzen HC, Maguire HC Jr (1983) The etiology of renal-cell carcinoma. Semin Oncol 10:378-384

2. Moore LE, Wilson RT, Campleman SL (2005) Lifestyle factors, exposures, genetic susceptibility, and renal cell cancer risk: a review. Cancer Invest 23:240-255

3. La Vecchia C, Negri E, Franceschi S, D'Avanzo B, Boyle P (1994) A case-control study of diabetes mellitus and cancer risk. Br J Cancer 70:950-953

4. Lindblad P, Chow WH, Chan J et al (1999) The role of diabetes mellitus in the aetiology of renal cell cancer. Diabetologia 42:107-112

5. Renehan AG, Frystyk J, Flyvbjerg A (2006) Obesity and cancer risk: the role of the insulin-IGF axis. Trends Endocrinol Metab $17: 328-336$

6. Washio M, Mori M, Khan M et al (2007) Diabetes mellitus and kidney cancer risk: the results of Japan Collaborative Cohort Study for Evaluation of Cancer Risk (JACC Study). Int J Urol 14:393-397

7. Calle EE, Kaaks R (2004) Overweight, obesity and cancer: epidemiological evidence and proposed mechanisms. Nat Rev Cancer 4:579-591

8. Segev Y, Landau D, Marbach M, Shehadeh N, Flyvbjerg A, Phillip M (1997) Renal hypertrophy in hyperglycaemic non-obese diabetic mice is associated with persistent renal accumulation of insulin-like growth factor I. J Am Soc Nephrol 8:436-444

9. Flyvbjerg A, Bornfeldt KE, Marshal SM, Arnqvist HJ, Orskov H (1990) Kidney IGF-1 mRNA in initial renal hypertrophy in experimental diabetes in rats. Diabetologia 33:334-338

10. Pekonen F, Partanen S, Rutanen EM (1989) Binding of epidermal growth factor and insulin-like growth factor 1 in renal cell carcinoma and adjacent normal kidney tissue. Int $\mathrm{J}$ Cancer 43:1029-1033

11. Kellerer M, von Eye Corleta H, Mühlhöfer A et al (1995) Insulin and insulin-like growth factor-1 receptor tyrosine-kinase activities in human renal carcinoma. Int J Cancer 62:501-507

12. Oka H, Chatani Y, Hoshino R et al (1995) Constitutive activation of mitogen-activated protein (MAP) kinases in human renal cell carcinoma. Cancer Res 55:4182-4187

13. Steinberg P, Storkel S, Oesch F, Thoenes W (1992) Carbohydrate metabolism in human renal clear cell carcinomas. Lab Invest 67:506-511

14. Flyvbjerg A (2000) Putative pathophysiogical role of growth factors and cytokines in experimental diabetic kidney disease. Diabetologia 43:1205-1223

15. Werner H, Shen-Orr Z, Stannard B, Burguera B, Roberts CT, LeRoith D (1990) Experimental diabetes increases insulin-like growth factor 1 and 2 receptor concentration and gene expression in kidney. Diabetes 39:1490-1497

16. Ariston RN, Feudale EL (1967) Introduction of renal tumour by streptozotocin in rats. Nature 214:1254-1255

17. Mauer SM, Lee CS, Najarian JS, Brown DM (1974) Induction of malignant kidney tumors in rats with streptozotocin. Cancer Res 34:158-160 
18. Bannasch P, Schacht U, Storch E (1974) Morphogenese und Mikromorphologie epithelialer Nierentumoren bei Nitrosomorpholin-vergifteten Ratten. I. Induktion und Histologie der Tumoren [Morphogenesis and micromorphology of epithelial renal tumours in nitrosomorpholin-treated rats. I. Tumour induction and histology]. Z Krebsforsch 81:311-331

19. Bannasch P, Zerban H (1990) Animal models and renal carcinogenesis. In: Eble J (ed) Tumors and tumor-like conditions of the kidneys and ureters. Churchill Livingstone, New York, pp $1-34$

20. Tsuda H, Iwase T, Matsumoto K et al (1998) Histogenetic stereological reconstruction of rat basophilic, clear and oncocytic neoplastic renal cell lesions using carbonic anhydrase type II-PAS double-stained sections. Toxicol Pathol 26:769-776

21. Ito N, Johno J, Marugami M, Konishi Y, Hiasa Y (1966) Histopathological and autoradiographic studies on kidney tumors induced by N-nitrosodimethylamine in rat. Gann 57:595-604

22. Bannasch P, Schacht U (1968) Nitrosamin-induzierte tubuläre Glykogenspeicherung und Geschwulstbildung in der Rattenniere [Nitrosamin-induced tubular glycogenosis and tumors in the rat kidney]. Virchows Arch B Cell Pathol 1:95-97

23. Bannasch P, Krech R, Zerban H (1978) Morphogenesis and micromorphology of epithelial tumors induced in the rat kidney by nitrosomorpholine. II. Tubular glycogenosis and the genesis of clear or acidophilic cell tumors. Z Krebsforsch Klin Onkol Cancer Res Clin Oncol 92:63-86

24. Bannasch P, Hacker HJ, Tsuda H, Zerban H (1986) Aberrant regulations of carbohydrate metabolism and metamorphosis during renal carcinogenesis. In: Weber $G$ (ed) Advances in enzyme regulation. Pergamon, Oxford, pp 279-296

25. Lubensky IA, Gnarra JR, Bertheau P, Walther MM, Linehan WM, Zhuang Z (1996) Allelic deletions of the VHL gene detected in multiple microscopic clear cell renal lesions in von Hippel-Lindau disease patients. Am J Pathol 149:2089-2094

26. Cao Y, Karsten U, Zerban H, Bannasch P (2000) Expression of MUC1, Thomsen-Friedenreich-related antigens, and cytokeratin 19 in human renal cell carcinomas and tubular clear cell lesions. Virchows Arch 436:119-126

27. Armanni L (1875) Di alcune lesioni nel diabete. Analisi istologia. [Diabetic lesions. A histological analysis]. In: Cantani A (ed) Patologia e terapia del ricambio materiale. [Pathology and therapy of metabolism]. Villardi, Milan, pp 301-310

28. Ritchie S, Waugh D (1957) The pathology of Armanni-Ebstein diabetic nephropathy. Am J Pathol 33:1035-1057

29. Hessner MJ, Wang X, Meyer L et al (2004) Involvement of Eotaxin, eosinophils, and pancreatic predisposition in development of type 1 diabetes mellitus in the biobreeding rat. J Immunol 173:6992-7002

30. Mathieu C, Kuttler B, Waer M, Bouillon R, Hahn HJ (1994) Spontaneous reestablishment of self-tolerance in $\mathrm{BB} / \mathrm{Pfd}$ rats. Transplantation 58:349-354

31. Dombrowski F, Lehringer-Polzin M, Pfeifer U (1994) Hyperproliferative acini after intraportal islet transplantation in streptozotocin-induced diabetic rats. Lab Invest 71:688-699

32. Dombrowski F, Bannasch P, Pfeifer U (1997) Hepatocellular neoplasms induced by low-number pancreatic islet transplants in streptozotocin-diabetic rats. Am J Pathol 150:1071-1087

33. Evert M, Sun J, Pichler S, Slavova N, Schneider-Stock R, Dombrowski F (2004) Insulin receptor, insulin receptor substrate-1, Raf-1, and Mek-1 during hormonal hepatocarcinogenesis by intrahepatic pancreatic islet transplantation in diabetic rats. Cancer Res 64:8093-8100

34. Scharf JG, Ramadori G, Dombrowski F (2000) Analysis of the IGF axis in preneoplastic hepatic foci and hepatocellular neoplasms developing after low-number pancreatic islet transplantation into the livers of streptozotocin diabetic rats. Lab Invest 80:1399-1411

35. Lojda Z, Grossau R, Schiebler TH (1979) Enzyme histochemistry. Springer, Berlin, Heidelberg, New York

36. Hacker HJ, Grobholz R, Klimek F (1991) Enzyme histochemistry and biochemical microanalysis of preneoplastic lesions. In: Graumann W, Drukker J (eds) Progress in histo- and cytochemistry. Fischer, Stuttgart, pp 61-72

37. Ahn YS, Zerban H, Grobholz R, Bannasch P (1992) Sequential changes in glycogen content, expression of glucose transporters and enzymic patterns during development of clear/acidophilic cell tumors in rat kidney. Carcinogenesis 13:2329-2334

38. Nogueira E, Klimek F, Weber E, Bannasch P (1989) Origin of rat renal clear cell tumors from the collecting duct. Virchows Arch B Cell Pathol 57:275-283

39. Dombrowski F, Filsinger E, Bannasch P, Pfeifer U (1996) Altered liver acini induced in diabetic rats by portal vein islet isografts resemble preneoplastic hepatic foci in their enzymic pattern. Am J Pathol 148:1249-1256

40. Dombrowski F, Mathieu C, Evert M (2006) Hepatocellular neoplasms induced by low-number pancreatic islet transplants in autoimmune diabetic BB/Pfd rats. Cancer Res 66:1833-1843

41. Bannasch P, Klimek F, Mayer D (1997) Early bioenergetic changes in hepatocarcinogenesis: preneoplastic phenotypes mimic responses to insulin and thyroid hormone. J Bioenerg Biomembr 29:303-313

42. Nehrbass D, Klimek F, Bannasch P (1998) Overexpression of insulin receptor substrate-1 emerges early in hepatocarcinogenesis and elicits preneoplastic hepatic glycogenosis. Am J Pathol 152:341-345

43. Radaeva S, Li Y, Hacker HJ, Burger V, Kopp-Schneider A, Bannasch P (2000) Hepadnaviral hepatocarcinogenesis: in situ visualization of viral antigens, cytoplasmic compartmentation, enzymic patterns, and cellular proliferation in preneoplastic hepatocellular lineages in woodchucks. J Hepatol 33:580-600

44. Bannasch P, Schröder CH (2002) Pathogenesis of primary liver tumours. In: MacSween RNM, Burt AD, Portman BC, Ishak KG, Scheuer PJ, Anthony PP (eds) Pathology of the liver. Churchill Livingstone, New York, pp 777-825

45. Rasch R, Gotzsche O (1988) Regression of glycogen nephrosis in experimental diabetes after pancreatic islet transplantation. APMIS 96:749-754

46. Bannasch P, Nogueira E, Zerban H, Beck K, Mayer D (1988) Sequential phenotypic conversion of renal epithelial cells during neoplastic development. In: Feo F, Pani P, Columbano A, Garcea R (eds) Chemical carcinogenesis. Springer, Berlin Heidelberg New York, pp 209-216

47. Uhlman DL, Nguyen P, Manivel JC et al (1995) Epidermal growth factor receptor and transforming growth factor alpha in papillary and nonpapillary renal cell carcinoma: correlation with metastatic behavior and prognosis. Clin Cancer Res 1:913-920

48. Everitt JI, Walker CL, Goldsworthy TW, Wolf DC (1997) Altered expression of transforming growth factor alpha: An early event in renal carcinoma development. Mol Carcinog 19:213-219

49. Dombrowski F, Evert M (2006) Diabetic tubular glycogenosis (Armanni-Ebstein-Lesion) is a preneoplastia of renal cell carcinomas in spontaneously-diabetic BB-rats. Pathol Res Pract 202:292, Abstr. 